\title{
Laboratory methods for producing of effective adsorbents on the basis of diatomite for purification of water from impurities of well-soluble organic compounds
}

\author{
(C) Yulia A. Ubaskina, ${ }^{1+}$ and Marina B. Alekhina ${ }^{2 *}$ \\ ${ }^{1}$ Laboratory of Custom Organic synthesis. Institute for Chemical Reagents and High Purity Chemical \\ Substances of NRC «Kurchatov Institute». Bogorodsky Val., 3. Moscow, 107076. Russia. \\ Phone:+7 (495) 963-70-70.E-mail: baseou@yandex.ru \\ ${ }^{2}$ Department of Technology of Inorganic Substances and Eelectrochemical Pprocesses. D. Mendeleev \\ University of Chemical Technology of Russia. Geroev Panfilovtsev St., 20. Moscow, 125480. Russia. \\ Phone: +7 (495) 495-21-57, ext. 50-87. E-mail: mbalekhina@yandex.ru
}

\begin{abstract}
*Supervising author; ${ }^{+}$Corresponding author
Keywords: diatomite, adsorbent, powder, granule, water, purification, highly soluble organic compounds.
\end{abstract}

\begin{abstract}
Today there is the problem of fine water purification during its consumption and disposal in industry from impurities of water-soluble organic compounds that enter it with pharmaceutical, cosmetic preparations, food waste, waste from the textile and chemical industries. Diatomite is a good raw material for the production of these adsorbents. It is found that diatomite is the mesoporous sorbent. The permeability of diatomite can be increased by granulating of the rock. It is found that heat treatment is necessary to obtain more durable granules from diatomite: when the increasing in the temperature of heat treatment of granules the compressive strength of granules increases too. At the same time, when the temperature of the heat treatment is increasing, the equilibrium adsorption of methylene blue on diatomite granules is decreasing. The optimum temperature for the heat treatment of granules is $550{ }^{\circ} \mathrm{C}$. It is found that the heat treatment and granulation of diatomite do not have a significant impact on the adsorptive-structural properties of the rock: up to $70 \%$ of the pore volume of granules is the volume of mesopores. The powdered adsorbent from diatomite which can be obtained by the developed laboratory method can be used in industrial water purification schemes where static adsorption is used for fine water purification. Using the developed laboratory method for producing granular adsorbent from diatomite, it is possible to produce an adsorbent for water purification under dynamic adsorption conditions, where a high value of the sorbent permeability is important.
\end{abstract}

\section{References}

[1] A.D. Pykina, S.O. Kazancev, I.V. Martemyanova. Comparative studies of the effectiveness of removal of iron and demanganation of groundwater in the use of known catalytic materials. XIX international scientific-practical conference named after Professor L.P. Kulev students and young scientists «Chemistry and chemical technology in the XXI century». Tomsk: Tomsk Polytechnic University Publ. 2018. P.121-122. (russian)

[2] A.A. Churaev, V.F. Sil'chenko. Substantiation of contact coagulation method application on water purification plants in town Novocherkassk. Ecology and water management. 2019. No.2. P.35-44. (russian)

[3] U.G. Distanov. Raw material base of siliceous rocks of the USSR and their use in the national economy. Ed. V.P. Petrov. Moscow: Nedra Publ. 1976. 104p. (russian)

[4] R.D. Crangle. Diatomite. In book: Mineral commodity summaries 2019. Reston, NV: U.S. Geological Survey. 2019. P.56-57.

[5] M.A. Al-Ghouti, M.A.M. Khraisheh, S.J. Allen, M.N. Ahmad. The removal of dyes from textile wastewater: a study of the physical characteristics and adsorption mechanisms of diatomaceous earth. Journal of Environmental Management. 2003. Vol.69. No.3. P.229-238. DOI: 10.1016/j.jenvman.2003.09.005

[6] R.A. Shawabkeh, M.F. Tutunji. Experimental study and modeling of basic dye sorption by diatomaceous clay. Applied Clay Science. 2003. Vol.24. No.1-2. P.111-120. DOI: 10.1016/s0169-1317(03)00154-6 
[7] E. Erdem, G. Çölgeçen, R. Donat. The removal of textile dyes by diatomite earth. Journal of Colloid and Interface Science. 2005. Vol.282. No.2. P.314-319. DOI: 10.1016/j.jcis.2004.08.166

[8] K.R. Ramakrishna, T. Viraraghavan. Dye removal using low cost adsorbents. Water Science and Technology. 1997. Vol.36. No.2-3. P.189-196. DOI: 10.2166/wst.1997.0516

[9] Z.H. Yu, S.R. Zhai, H. Guo, Y. Song, F. Zhang, H.C. Ma. Removal of methylene blue over low-cost mesoporous silica nanoparticles prepared with naturally occurring diatomite. Journal of Sol-Gel Science and Technology. 2018. Vol.88. No.3. P.541-550.

[10] E.A. Mohamed, A.Q. Selim, A.M. Zayed, S. Komarneni, M. Mobarak, M.K. Seliem. Enhancing adsorption capacity of Egyptian diatomaceous earth by thermo-chemical purification: Methylene blue uptake. Journal of colloid and interface science. 2019. Vol.534. P.408-419. DOI: 10.1016/j.jcis.2018.09.024

[11] S. Yan, W. Huo, J. Yang, X. Zhang, Q. Wang, L. Wang, Y. Pan, Y. Huang. Green synthesis and influence of calcined temperature on the formation of novel porous diatomite microspheres for efficient adsorption of dyes. Powder Technology. 2018. Vol.329. P.260-269. DOI: 10.1016/j.powtec.2018.01.090

[12] X. Gong, W. Tian, L. Wang, J. Bai, K. Qiao, J. Zhao. Biological regeneration of brewery spent diatomite and its reuse in basic dye and chromium (III) ions removal. Process Safety and Environmental Protection. 2019. Vol.128. P.353-361. DOI: 10.1016/j.psep.2019.05.024

[13] Z. Medjdoubi, M. Hachemaoui, B. Boukoussa, A. Hakiki, A. Bengueddach, R. Hamacha. Adsorption behavior of Janus Green B dye on Algerian diatomite. Materials Research Express. 2019. Vol.6. No.8. P.1-13. DOI: $10.1088 / 2053-1591 / \mathrm{ab} 2732$

[14] D.V. CHerkasov. Portland cement with the addition of modified diatomites and composites based on them. Cand. Diss. Saransk. 2014. 177p. (russian)

[15] J.A. Ubaskina, I.V. Arsentiev, E.G. Fetyukhina, J.A. Korostelyova, T.V. Adaev. Study of mineralogical composition of diatomite for its safe mining and industrial usage. Bulletin of Belgorod State Technological University named after V.G. Shukhov. 2016. No.1. P.128-132. (russian)

[16] S.A. Lisin. Modification of biogenic silica and ways of its use. Cand. Diss. Ul'yanovsk. 2004. 144p. (russian)

[17] M. Duc, F. Gaboriaud, F. Thomas. Sensitivity of the acid-base properties of clays to the methods of preparation and measurement: 1. Literature review. Journal of colloid and interface science. 2005. Vol.289. No.1. P.139-147. DOI: 10.1016/j.jcis.2005.03.060

[18] A.I. Seryh. Formation, nature and physicochemical properties of cationic centers in catalytic systems based on high-silica zeolites. Doc. Diss. Moscow. 2014. 347p. (russian)

[19] Siliceous rocks of the USSR. Ed. U.G. Distanov Kazan: Tatar book Publishing House. 1976. 412p. (russian)

[20] G.R. Bell. Design criteria for diatomite filters. Journal American Water Works Association. 1962. Vol.54. No.10. P.1241-1256. DOI: 10.1002/j.1551-8833.1962.tb00964.x

[21] C.A. Frankenhoff. Recovery of diatomaceous earth. Patent US. No. 2946755. 1960. 3p.

[22] J.A. Ubas'kina, E.N. Ofitserov. E.G. Fetyuhina. Diatomite as a source of silica for chemical industry. Resources. Technologies. Economy. 2005. No.12. P.10-13. (russian)

[23] Integrated water consumption and sanitation standards for various industries. Ed. I.V. Soboleva. 2nd ed. Revised. Moscow: Stroyizdat. 1982. 528p. (russian) 